BJHS 53(1): 1-24, March 2020. C The Author(s), 2019. Published by Cambridge University Press on behalf of British Society for the History of Science. This is an Open Access article, distributed under the terms of the Creative Commons Attribution licence (http://creativecommons. org/licenses/by/4.0/), which permits unrestricted re-use, distribution, and reproduction in any medium, provided the original work is properly cited.

doi:10.1017/S0007087419000529 First published online 11 October 2019

\title{
Tremoring transits: railways, the Royal Observatory and the capitalist challenge to Victorian astronomical science
}

\author{
EDWARD J. GILLIN*
}

\begin{abstract}
Britain's nineteenth-century railway companies traditionally play a central role in histories of the spread of standard Greenwich time. This relationship at once seems to embody a productive relationship between science and capitalism, with regulated time essential to the formation of a disciplined industrial economy. In this narrative, it is not the state, but capitalistic private commerce which fashioned a national time system. However, as this article demonstrates, the collaboration between railway companies and the Royal Greenwich Observatory was far from harmonious. While railways did employ the accurate time the observatory provided, they were also more than happy to compromise the astronomical institution's ability to take the accurate celestial observations that such time depended on. Observing astronomical transits required the use of troughs of mercury to reflect images of stars, but the construction of a railway too near to the observatory threatened to cause vibrations which would make such readings impossible. Through debates over proposed railway lines near the observatory, it becomes clear how important government protection from private interests was to preserving astronomical standards. This article revises our understanding of the role of railway companies in the dissemination of standard time and argues that state intervention was essential to preserving Victorian British astronomical science.
\end{abstract}

The harmonious relationship between the Royal Observatory at Greenwich and Britain's fast-expanding railway network has been central to traditional histories of the spread of national standard time. Until the mid-nineteenth century, towns and cities had

* Faculty of Music, University of Cambridge, 11 West Road, Cambridge, CB3 9DP, UK.

Email: Edward.gillin@cantab.net.

This paper was generously funded by the ERC through the Sound and Materialism in the Nineteenth Century project, hosted at the University of Cambridge's Faculty of Music. Thanks go to colleagues Melle Kromhout, Veronika Lorenser, Stephanie Probst, David Trippett and Melissa van Drie for all their help and support. Thanks are also due to Dániel Bélteki, Jim Bennett, Jenny Bulstrode, Stephen Courtney, Louis Devoy, Graham Dolan, Graeme Gooday, Rebekah Higgitt, Harry Mace, Lee Macdonald, Emma Saunders, Simon Schaffer, Steve and Louise Spencer, Crosbie Smith and Oliver Zimmer. I am grateful to the staff in Rare Books and the Manuscripts Room at Cambridge University Library. An earlier version of this paper was read at the workshop on the life and work of Sir George Biddell Airy, held at Cambridge University Library in June 2018, where the discussion was invaluable. I would like to thank Charlotte Sleigh, Trish Hatton, and the two constructive reviewers at the BJHS. Finally, much of the credit for this article is due to my grandfather, Robert White, who fuelled my interest in steam trains from an early age: I hope he enjoys reading it. 
maintained their own local times, dependent on solar observations, but with the rise of rail travel there was increasing urgency for a standard system of time regulation. From 1840, the Great Western Railway ordered London time to be used across its network, with other companies soon following this practice. In 1845 the Liverpool and Manchester Railway Company petitioned Parliament to introduce uniform time for the nation's 'ordinary and commercial purposes', while companies lobbied government in the late 1840s for a standard legal time. Although private railway companies were all running to Greenwich time by 1848 , the government did not legally adopt the standard until 1880. As Derek Howse put it, it was 'the railways that eventually forced a uniform time on a not-unwilling population', while Allan Chapman concluded, 'Railway stations and telegraph offices now replaced church clocks as the foremost time sources in the community, and brought the role of the Observatory, and its director, before the nation'. ${ }^{1}$ Here, then, was a celebrated example of a mutually beneficial exchange between science and commerce, between financial capital and knowledge. Specifically, it was the partnership between the Astronomer Royal George Biddell Airy (18011892) and the South Eastern Railway Company's (SER) telegraph engineer, Charles Walker (1812-1882), in establishing a telegraphic connection between the Royal Observatory and SER stations at Lewisham and London Bridge in 1852, that helped disseminate Greenwich time across the nation and, eventually, the globe. ${ }^{2}$ Summing up his preference for private capitalistic, rather than governmental, collaboration, Airy declared that 'our national genius inclines us to prefer voluntary associations of private persons to organizations of any kind dependent on the state'. Reflecting on the role of the British Association for the Advancement of Science, established in 1831 to lobby for government funding of scientific enterprise, Airy argued that it was acceptable for the state to provide an administrative role in 'any branch of science' which required 'continued administrative routine', such as the Royal Observatory. But, speaking as the British Association's president in 1851, Airy trusted 'that in all cases the initiative of Science will be left to individuals or to independent associations'. ${ }^{3}$

1 Derek Howse, Greenwich Time and the Longitude, London: Philip Wilson, 1997, p. 92; Allan Chapman, 'Sir George Airy (1801-1892) and the concept of international standards in science, time keeping and navigation', Vistas in Astronomy (1985) 28, pp. 321-328, 325. Clock time was central to Thompson's classic account of the formation of industrial capitalism; see E.P. Thompson, 'Time, work-discipline, and industrial capitalism', Past and Present (December 1967) 38, pp. 56-97; on standard time and the regulation of the economy see David Rooney and James Nye, "Greenwich Observatory time for the public benefit": standard time and Victorian networks of regulation', BJHS (2009) 42(1), pp. 5-30.

2 Howse, op. cit. (1), pp. 92-95; Iwan Rhys Morus, “The nervous system of Britain”: space, time and the electric telegraph in the Victorian age', BJHS (2000) 33(4), pp. 455-475, 464-470; also see A.J. Meadows, Greenwich Observatory: One of Three Volumes by Different Authors Telling the Story of Britain's Oldest Scientific Institution the Royal Observatory at Greenwich and Herstmonceux, 1675-1975, vol. 2: Recent History (1836-1975), London: Taylor and Francis, 1975, pp. 69-70; on the scriptural grounding of Airy's work to disseminate standard time see Stephen Courtney, 'The historical meridian: antiquity and scripture in the public work of George Biddell Airy', Journal for the History of Astronomy (2018) 49(2), pp. 135$157,150-152$.

3 Airy quoted in Jack Morrell and Arnold Thackray, Gentlemen of Science: Early Years of the British Association for the Advancement of Science, Oxford: Oxford University Press, 1981, p. 353; also in Martin Daunton, State and Market in Victorian Britain, Woodbridge: Boydell Press, 2008, pp. 19-20; for Airy's 
Despite Airy's optimism, the relationship between the Royal Observatory and private railway companies, especially the SER, was far more complex than is suggested in accounts of the establishing of Greenwich time as a national standard. By examining various proposals to construct a railway through Greenwich Park, notably between 1835 and 1836, 1845 and 1846, and 1863 until 1865, it becomes apparent that Victorian notions of a reciprocal union between capital and science were often idealistic. Through an examination of these three railway schemes, I show how the Royal Observatory was, for over thirty years, in conflict with the very railways which became so crucial to fulfilling its aspirations for telegraphically distributed time. The construction of a railway too close to the observatory threatened to undermine its ability to take the accurate astronomical observations required to determine time; recording celestial transits involved seeing stars reflected from a horizontal surface of mercury, but the passing of heavy steam locomotives produced vibrations which interfered with the mercurial fluid. Although Airy and several other astronomical authorities devised intricate experiments to show the damage a railway would cause to the observatory, railway companies continually rejected or ignored such evidence. It was cheaper to build through the park at the expense of the observatory than to construct a line through housing further north, and successive companies were happy to put these savings ahead of Britain's astronomical science. By the 1860s, the SER was seriously proposing the removal of the observatory from Greenwich altogether. ${ }^{4}$

At the heart of these discussions was the problem of what constituted a plausible engineering experiment and who was a competent judge to interpret experimental results. Those opposing and those rejecting the various railway schemes both employed very similar experimental techniques and often produced similar findings. But protagonists used this experimental evidence in very different ways to make contrasting claims concerning what was a safe distance between a railway and the observatory. This was, above all, a problem of replication, or what Harry Collins has described as 'experimenters' regress', in which a scientific practitioner, examining a phenomenon for the first time, has to rely on their practical knowledge to judge whether the experiment has worked in terms of whether it has produced the results expected based on their previous experiences. ${ }^{5}$ In the case of an experimental arrangement intended to

views on state intervention in the corn market see Jenny Bulstrode, 'Riotous assemblage and the materials of regulation', History of Science (2018), pp. 1-36, 27, available at http://journals.sagepub.com/doi/abs/10. $1177 / 0073275318776187$; on Victorian convictions that commerce and science were mutually advantageous, with the railway's role in spreading standard time as an example, see Frank M. Turner, 'Practicing science: an introduction', in Bernard Lightman (ed.), Victorian Science in Context, Chicago: The University of Chicago Press, 1997, pp. 283-289, 286-287; compare with the role of universities in disseminating time explored in William B. Black and David Clarke, 'Glasgow time signals', Journal for the History of Astronomy (2016) 47(3), pp. 256-293.

4 The Royal College of Science at South Kensington faced a similar threat to its laboratory work from vibrations and electrical interference during the 1890s when a new underground railway was proposed near the institution. This is explored in Sophie Forgan and Graeme Gooday, " "A fungoid assemblage of buildings": diversity and adversity in the development of college architecture and scientific education in nineteenth-century South Kensington', History of Universities (1994) 13, pp. 153-192, 176-182.

5 See H.M. Collins, Changing Order: Replication and Induction in Scientific Practice, London: SAGE Publications, 1985, pp. 2, 29-49. 
model the interference of railway traffic with the intricate laboratory work of the observatory, it was unclear how this could practically be done and how the results should be interpreted. Throughout this article it becomes apparent that different actors, with contrasting levels of competence and interests, were performing very similar experiments, but drawing different conclusions. At stake here were differences between railway promoters and those who claimed specialist astronomical expertise about what constituted a significant tremor. ${ }^{6}$

My analysis of these disputes between the observatory and the promoters of a park railway does two things. Primarily, it shows that for all its apparent permanence, the observatory's survival at Greenwich was far from inevitable during the nineteenth century. Although the observatory did eventually relocate to Herstmonceux in the mid-twentieth century, the institution's reputation in Victorian society appears as one of stability and growth. Its location seemed incontestable in 1884 at the International Meridian Conference in Washington, where Greenwich was determined as the global prime meridian (alternatives included Paris and Jerusalem) at the heart of an international time system. ${ }^{7}$ Before this, both the observatory and its influence had grown constantly. Its number of staff, instruments and buildings increased, including the installation of large equatorial and altazimuth telescopes with view-protecting domes during the 1850s, a Photographic and Spectroscopic Department in 1873, and a Solar Department in the same year. This was followed by the New Library for observatory paperwork, built between 1878 and 1882, and the New Physical Observatory in the 1890 s. $^{8}$ Though architecturally constrained and erratically planned, the theme of the observatory in this time was of growth. With railways employing Greenwich time in the 1840s, post offices conveying it from 1872, and its adoption as 'legal time' in 1880 , the institution's influence expanded too. The observatory was a symbol of the ordered business and social life of the empire, with Airy confident that its work of recording and disseminating accurate time 'disciplin[ed] the useful work of the nation'. However, much of this happened within the context of uncertainty. The observatory being a far from stable bastion of imperial Victorian science, for much of the nineteenth century its future was threatened by railway companies eager to make a quick profit. Ben Marsden and Crosbie Smith have emphasized that the 'Royal Observatory's authority in the later nineteenth century as the great regulator of the nation's time ... had been neither inevitable nor self-evident'. It was not just the observatory's authority that was far from inherent; its very location and existence were open to question. ${ }^{10}$ In debates over new railway schemes, the observatory was just one interest, competing with those of commercial companies, the Admiralty, Parliament and local inhabitants in Greenwich and Kent.

6 I am grateful to an anonymous BJHS reviewer for these observations.

7 Rebekah Higgitt and Graham Dolan, 'Greenwich, time and "the line", Endeavour (2010) 34(1), pp. 35-39.

8 Rebekah Higgitt, 'A British national observatory: the building of the New Physical Observatory at Greenwich, 1889-1898', BJHS (2014) 47(4), pp. 609-635, 612, 616, 622-624.

9 Ben Marsden and Crosbie Smith, Engineering Empires: A Cultural History of Technology in NineteenthCentury Britain, Basingstoke: Palgrave Macmillan, 2005, p. 20.

10 Marsden and Smith, op. cit. (9), p. 17. 
The second point of this article is to contribute to broader historical understandings of the Victorian relationship between science and capitalism. While historians like Peter Mandler and Jonathan Parry have challenged traditional assumptions over the extent to which the Victorian state can be described as laissez-faire, there was a consensus in nineteenth-century Britain that industry and science were mutually enhancing and required minimal government interference. ${ }^{11}$ Nevertheless, though the state was small, it was far from inactive. Martin Daunton has shown that while state spending decreased, the government provided moral regulation and anti-monopolization legislation for the economy. ${ }^{12}$ During the railway boom of the 1830 s and 1840 s even the most pro-freetrade administrations intervened over questions of safety, property rights and standardization, while new lines were accompanied by Acts of Parliament. ${ }^{13}$ For example, the regulation of track to a gauge of 4 feet $81 / 2$ inches passed into law in $1846 .{ }^{14}$ Yet for all this, British liberalism and free trade were actively celebrated, with economic and political freedoms loudly proclaimed. Within this, the place of science was important. Government spending on science decreased throughout the century, but such knowledge was heralded as the great aid to industry. The cultivation of scientific knowledge was, ideally, to be entrusted to private enterprise; science was often thought to develop best in a liberal economy, under the voluntary direction of capitalistic businesses and independent bodies, such as the universities or the British Association for the Advancement of Science. ${ }^{15}$ The leading liberal spokesman of the age and three-time prime minister, William Gladstone, summed up this consensus in 1890 when he asserted that it had been private railway companies who had done the most to create Britain's 'orderly life'. Likewise, forty years earlier, the director of the Liverpool and Manchester Railway, Henry Booth, had implicitly aligned the scientific standardization of time with the values of the capitalist. ${ }^{16}$ Perhaps no better example of this commercial promotion of science could be cited than the railway's dissemination of standard time.

11 Peter Mandler, 'Introduction: state and society in Victorian Britain', in Mandler (ed.), Liberty and Authority in Victorian Britain, Oxford: Oxford University Press, 2006, pp. 1-21; J.P. Parry, 'Liberalism and liberty', in Mandler, Liberty and Authority in Victorian Britain, op. cit., pp. 71-100; on scientific standards and businesses see M. Norton Wise, 'Precision: agent of unity and product of agreement. Part II: the age of steam and telegraphy', in Wise (ed.), The Values of Precision, Princeton, NJ: Princeton University Press, 1995, pp. 222-236.

12 Daunton, op. cit. (3), pp. 4-5; on science and the state also see Peter Alter, The Reluctant Patron: Science and the State in Britain, 1850-1920, Oxford: Berg, 1987.

13 For traditional railway histories see Jack Simmons, The Victorian Railway, London: Thames and Hudson, 1991; John R. Kellett, The Impact of Railways on Victorian Cities, London: Routledge, 1969; for a cultural history of railway expansion see Marsden and Smith, op. cit. (9), pp. 129-177, esp. 136-150; on the state's very limited inspectorate for railway safety see Sarah Crawford Dry, 'A chapter of accidents: science, safety and government in mid-Victorian Britain', University of Cambridge PhD dissertation, 2006.

14 R.A. Buchanan, 'Engineers and government in nineteenth-century Britain', in Roy Macleod (ed.), Government and Expertise: Specialists, Administrators and Professionals, 1860-1919, Cambridge: Cambridge University Press, 1988, pp. 41-58, 44-45.

15 Daunton, op. cit. (3), pp. 18-21; on liberalism and the liberal state see Patrick Joyce, The State of Freedom: A Social History of the British State since 1800, Cambridge: Cambridge University Press, 2013, pp. 5-6, 28-29.

16 Oliver Zimmer, 'Time tribes: time and the Other in Britain's railway age', forthcoming article for which I am grateful for an advanced reading, currently under review for the Journal of Modern History; on time 
Within a laissez-faire state, capitalistic companies had brought about the regulation of the nation. A closer inspection, however, reveals a more complex story in which astronomical science was in direct conflict with capital, and in which standard time advanced in spite of, rather than because of, railway expansion.

\section{The Greenwich and Gravesend Railway, 1835-1836}

In November 1834, shares went on sale in The Times for a newly proposed railway to link central London with Gravesend and east Kent. There had been much popular support for this measure at a public meeting held in Dover the previous May, and despite estimated construction costs of $£ 1.5$ million, it was reckoned that the line could generate an annual profit of about $£ 35,000 .{ }^{17}$ The London and Gravesend Railway Company advertised the sale of more shares in The Times the following October, releasing a detailed prospectus and this time attempting to raise $£ 600,000$. Claiming that Gravesend was a booming town, which had 'lately been growing in public estimation' as a resort for the metropolis, the company calculated that up to 900,000 people visited it each year, and stressed the commercial value of reducing the travelling time between London Bridge and the Port of London to under an hour, especially for the arrival of foreign mail. ${ }^{18}$ Part of this proposed railway would pass 850 feet from the Royal Observatory through a tunnel beneath Greenwich Park, but, fearing disruption to the astronomical institution, the company had to secure permission from the Admiralty and the government's Office of Woods and Forests (Figure 1). As Secretary to the Admiralty, the Whig MP Charles Wood (1800-1885) wrote to the Astronomer Royal, John Pond (1767-1836), asking for his opinion on the matter. Pond had no 'experience of the degree of concussion produced by the transit of heavy carriages on railways', but explained that the

most important observations made at the Royal Observatory are those in which the stars are seen by reflection from a horizontal surface of mercury. It appears to me highly probable ... that the passage of heavy carriages, even at the distance of the intended tunnel, might produce sufficient tremor on this surface to destroy the accuracy of these observations. ${ }^{19}$

Pond retired shortly after this, but the problem of railway vibrations was one of the first to face Airy on appointment as Astronomer Royal in late 1835. After graduating as senior wrangler in the Cambridge Mathematical Tripos examinations of 1823, Airy had been Cambridge's Lucasian Professor of Mathematics from 1826 and took responsibility for the University Observatory in $1828 .{ }^{20}$ At Greenwich, he worked to introduce

standardization see Stephen Kern, The Culture of Time and Space, 1880-1918, Cambridge, MA: Harvard University Press, 1983.

17 Anon., 'London and Gravesend Railway Company', The Times, 20 November 1834, p. 1; Anon., 'Railways', Morning Post, 21 May 1834, 3.

18 Anon., 'London and Gravesend Railway', The Times, 27 October 1835, p. 1.

19 Correspondence Relative to Railway Passing through Greenwich Park, 1834-1846, Parliamentary Paper (subsequently PP) 1846: 375, p. 4.

20 Allan Chapman, 'Airy, Sir George Biddell (1801-1892)', Oxford Dictionary of National Biography, Oxford University Press, 2004; online edn, January 2011, http://ezproxy.ouls.ox.ac.uk:2117/view/article/251, 


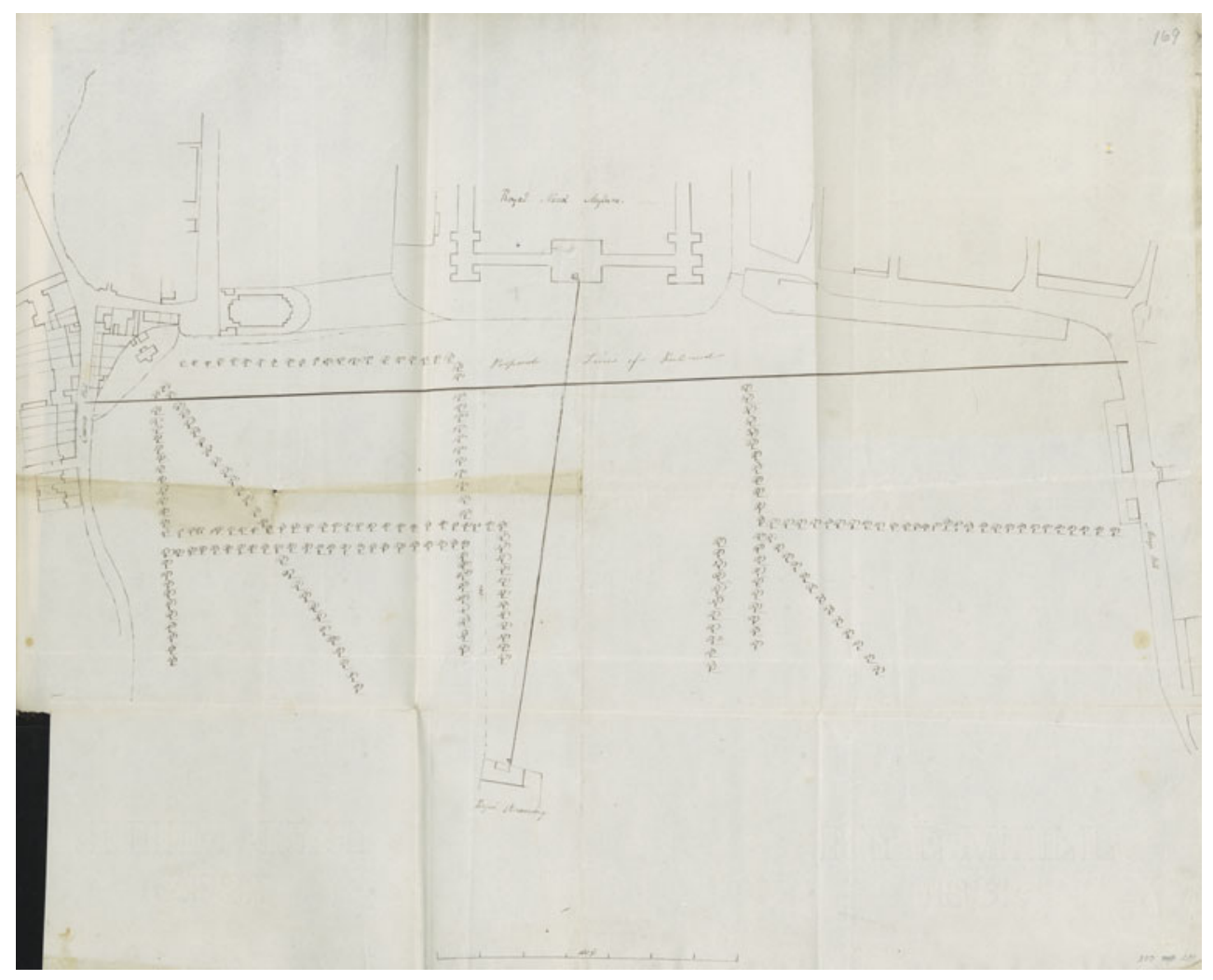

Figure 1. The proposed route through Greenwich Park as part of the Greenwich and Gravesend Railway, 1835. RGO/6/47, p. 169. Reproduced by kind permission of the Syndics of Cambridge University Library.

a highly disciplined system of astronomical observation, likened to a 'factory mentality', to secure accuracy. ${ }^{21}$ Airy agreed that the tremors of fast-moving trains would be 'particularly seen in the observations by reflexion in a trough of mercury, which observations, for the accuracy of modern astronomy, are quite indispensable'. ${ }^{22}$

On 9 January 1836 the Admiralty ordered an investigation into the effects of railway vibrations on astronomical observations; two weeks later, Airy conducted experiments along the existing Greenwich Railway near Croydon. ${ }^{23}$ The line was not yet in use,

accessed 11 January 2018; Chapman, 'George Biddell Airy, F.R.S. (1801-1892): a centenary commemoration', Notes and Records of the Royal Society of London (1992) 46(1), pp. 103-110.

21 Chapman, op. cit. (1), p. 323; Simon Schaffer, 'Astronomers mark time: discipline and the personal equation', Science in Context (1988) 2(1), pp. 115-145.

22 Royal Greenwich Observatory Archives (subsequently RGO)/6/47, 'Airy to Charles Wood', 4 February 1836 , p. $173 \mathrm{a}$.

23 RGO/6/47, 'Airy to the Secretary of the London and Gravesend Railway', 9 January 1836, p. 151; RGO/ 6/47, 'Airy to Landmann', 21 January 1836, p. 161; on Airy's relationship with the Admiralty see Caitlin 
but the company agreed to run trains for these observations after Airy had claimed it impossible to know the impact of vibrations without the use of full-sized locomotives. To replicate and measure the impact of vibration on an astronomical observation, Airy employed a collimator (a telescope with a needle suspended within), a telescope and a trough of mercury. The eyepiece of the collimator was directed at the sun and angled towards the trough, positioned on the ground, which created an image of the sun passing the telescope's wire. The telescope was in turn aimed at the mercury trough, magnifying the reflected transit image (Figure 2). This arrangement, Airy asserted, allowed for the observation of minute terrestrial vibrations. ${ }^{24}$ From observing the impact of nine passing trains at varying distances, Airy found a tremor was perceptible at up to 1,100 feet, while at 750 feet all astronomical observations using mercury were impossible. ${ }^{25}$

Despite requests to publish an account of these experiments in several publications, including the Journal of Science, Airy refused to make his findings public, believing them to be confidential government business. ${ }^{26}$ However, he provided details of the mercury-trough arrangement to the Admiralty, which commissioned further experiments to be performed on the Liverpool and Manchester Railway. The results of these Royal Navy observations at Liverpool found that vibrations of trains of 120 tons travelling at twenty-five miles per hour seriously affected mercury at up to 942 feet. Combined with Airy's findings, these observations convinced Charles Wood that the proposed railway would completely 'destroy the accuracy of the Observations' at the observatory. ${ }^{27}$ Under pressure from the Admiralty, the Greenwich and Gravesend Railway Company therefore abandoned its planned route through Greenwich Park in November $1836 .^{28}$

\section{'Mere matters of wrangling', 1845-1846}

With the exception of a short-lived scheme in 1840 from the London and Chatham Railway for a half-mile connection through the park, it was not until 1845 that the observatory once again faced a serious threat from a railway scheme. This time, however, it was the powerful SER which proposed an extension near the observatory, and this company pressed for the scheme with unprecedented vigour. This line would provide a direct communication between London and the military and naval arsenals and depots of Woolwich, Chatham, Sheerness and Canterbury. A further extension would connect this network to the existing line between Margate, Ramsgate,

Holmes, 'The Astronomer Royal, the Hydrographer and the time ball: collaborations in time signalling 18501910', BJHS (2009) 42(3), pp. 381-406.

24 RGO/6/47, 'Memorandum to Airy', 18 February 1836, p. 182.

25 RGO/6/47, 'Airy to Charles Wood', 4 February 1836, pp. 173-176.

26 RGO/6/47, 'Kempath to Airy', 11 February 1836, p. 192; RGO/6/47, ‘Airy to Kempath', 1 March 1836, p. 199.

27 PP 1846: 375, pp. 5-6.

28 Wilfrid Airy (ed.), Autobiography of Sir George Biddell Airy, Cambridge: Cambridge University Press, 1896, p. 126. 


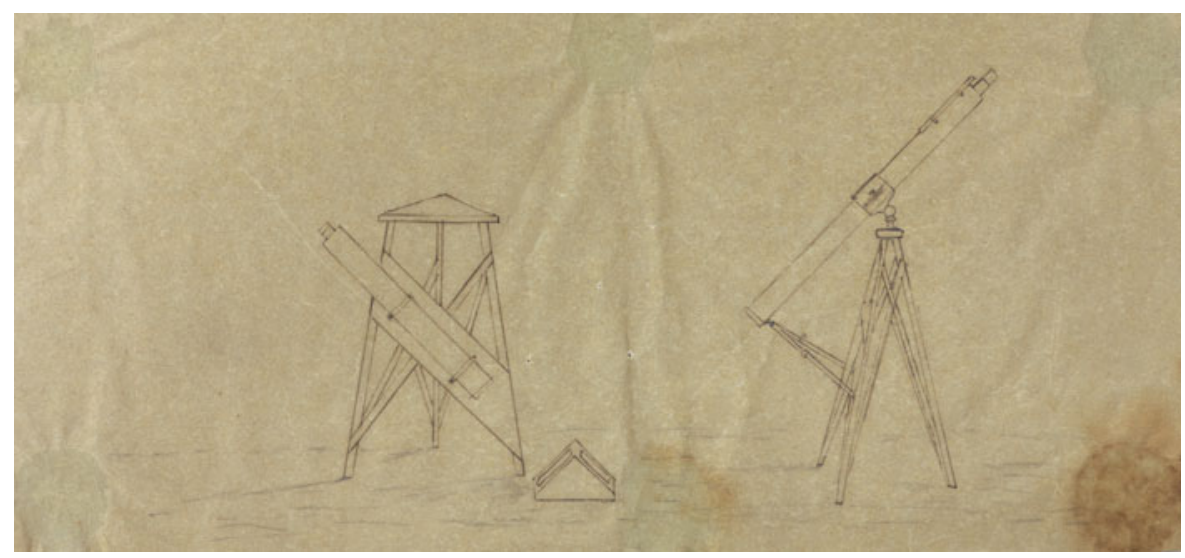

Figure 2. Airy's experimental arrangement for measuring railway vibrations, with the collimator on the left and the telescope on the right, both angled towards the triangular trough containing mercury. RGO/6/50, p. 302. Reproduced by kind permission of the Syndics of Cambridge University Library.

Sandwich, Deal and Dover. Not only was a line through Greenwich Park financially attractive, but the railway's promoters also claimed that the scheme would provide over 400,000 subjects, presently lacking direct rail access to London, a link to the capital. ${ }^{29}$

Initially the Lords Commissioners of the Admiralty reiterated their 1836 decision that no railway would be permitted through the park. However, a carefully worded enclosure from engineer Robert Stephenson (1803-1859) to the directors of the SER emphasized that he was prepared to cooperate with Airy to protect the observatory; a copy of this enclosure was sent to the Admiralty. A specialist in railway construction, Stephenson had attended Edinburgh University classes on chemistry, natural history and natural philosophy between 1822 and 1823. This combination of engineering and scientific knowledge made him an ideal collaborator for Airy's experiments. At the same time, this cooperation shows that Airy, despite often appearing overly theoretical, was eager to work alongside a practical engineer to resolve the problem of railway vibration. ${ }^{30}$ Stephenson described how the railway would be built 765 feet from the observatory in a tunnel twenty-five feet underground (Figure 3). Stephenson had Robert Dockray, the resident engineer of the London and Birmingham Railway, record observations on the effect of vibrations on the walls of the Euston Station extension during the passing of trains. Dockray had attempted to measure vibrations by using fine emery, but as he

29 Correspondence, op. cit. (19), p. 16; anon., 'The new projected railways', The Times, 18 January 1845, p. 5; on this scheme also see Airy, op. cit. (28), pp. 178-179.

30 Airy often appeared overly theoretical and inflexible, such as on the problem of magnetic compass deviation and iron ships, in which he was accused of ignoring the capricious nature of ocean travel. Explored in Alison Winter, “Compasses all awry”: the iron ship and the ambiguities of cultural authority in Victorian Britain', Victorian Studies (1994) 38(1), pp. 69-98, 74. 


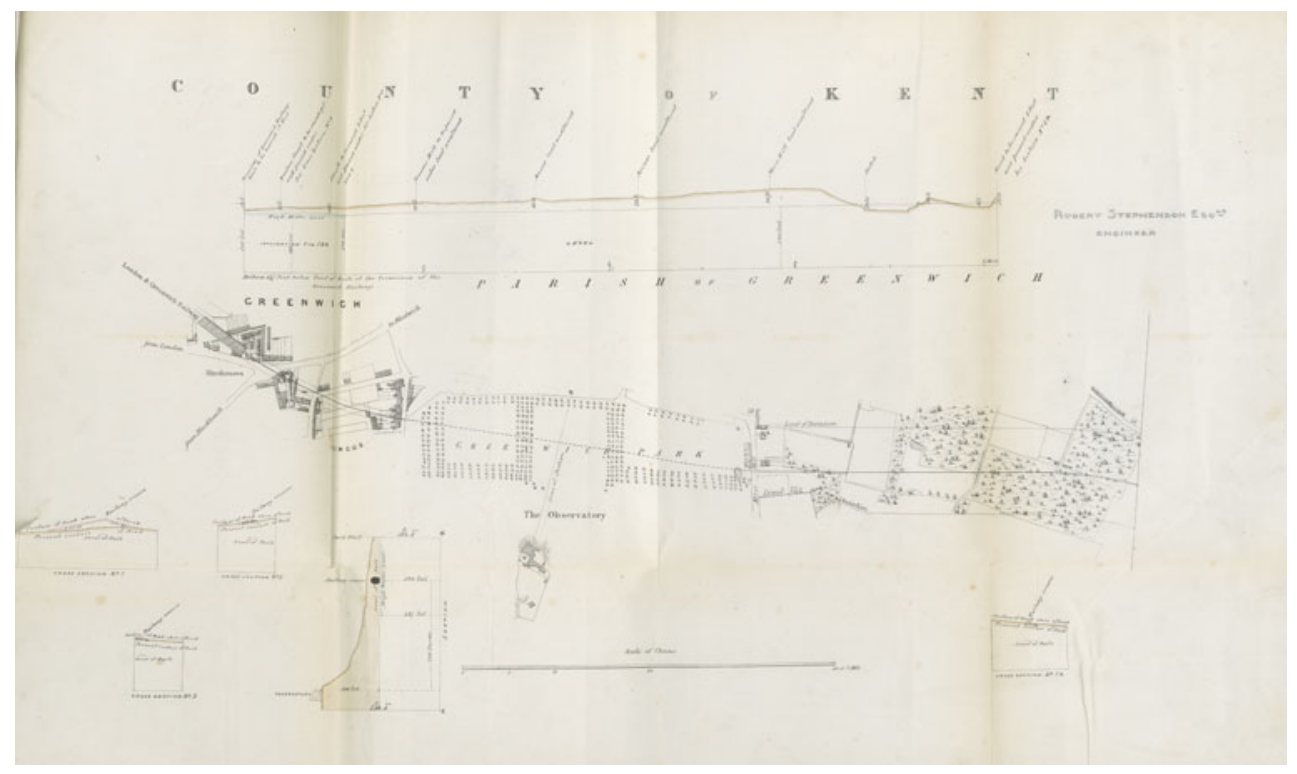

Figure 3. Robert Stephenson's proposed line through Greenwich Park. RGO/6/47, p. 253. Reproduced by kind permission of the Syndics of Cambridge University Library.

observed no disruption, Stephenson was unsatisfied with the use of powder and chose to conduct his own experiments using mercury. ${ }^{31}$ He placed in the ground, tightly packed with frozen soil, a circular cup, highly glazed and flat-bottomed, and covered in quicksilver. The vessel was protected from the wind, while Stephenson took care to keep the mercury free of oxidation by regular filtering. In his first six experiments he fixed the cup on the bank of a cutting and observed considerable agitation depending on the velocity of passing trains. He concluded that the tunnel reduced the impact of vibration on the standing mercury, but his experiments revealed that atmospheric vibrations were also noticeable. Stephenson reported that 'when the engine makes a deep booming sound by the vibration of the air in the chimney, a very decided effect is produced on windows in the neighbouring houses, so much so, that I have known the engine-house windows to be broken by it'. He surmised that these atmospheric vibrations were the only threat to the observatory, but believed that they would be contained if the proposed railway were housed in a tunnel. ${ }^{32}$ Here it was clear that, even when carrying out similar experiments, different practitioners drew different conclusions from inquiries.

Despite Stephenson's investigations, the Admiralty still opposed the rail connection. Unperturbed, Viscount Torrington and James MacGregor, the chair and deputy chair of the SER, wrote to the Admiralty, emphasizing the accuracy of Stephenson's 'careful experiments', which demonstrated that no vibrations could affect the observatory. 
They offered to finance further experiments, conducted under Airy's direction, in order to produce some 'facts' which could be trusted. ${ }^{33}$ Airy and Stephenson met in June 1845, with the Astronomer Royal impressed with the engineer's proposed tunnel; he believed that the structure invalidated his 1836 mercurial observations and suggested new experiments under circumstances which he might 'judge more analogous to those of the proposed line'. ${ }^{34} \mathrm{He}$ invited Stephenson to perform the trials with him, but specified that the 'experiments I wish to be regarded strictly as mine, to this extent, that nothing regarding them is to be published except by me'. Despite wanting to control the publication of these trials, Airy informed Stephenson that he was 'desirous that you or any of your friends should see and take part' in them. ${ }^{35}$ Using the London and Birmingham Railway, Airy and Stephenson identified the tunnel at Kensal Green as similar in length, depth and soil type as that proposed for Greenwich Park. In February 1846 a party, including Stephenson, Airy and his wife Richarda (18041875 , née Smith) set out to observe passing trains from Kensal Green Cemetery. After setting up the apparatus and mercury trough, they recorded the effects of several passing trains on the reflection of wires on the quicksilver, while Richarda Airy sketched her husband at work, as she had done when assisting him with his earlier experiments in 1836 (Figure 4). In total they observed five trains, followed by eight more on a return to the same location in March. Before making these observations, they acquired details of the weight and speed of different trains from the secretary of the London and Birmingham Railway. ${ }^{36}$

Based on these trials, Airy reported to the Admiralty that Stephenson's tunnel could potentially diminish the railway's impact on the observation of stars by reflection on quicksilver, which were so crucial to the observatory's timekeeping obligations. The Kensal Green experiments confirmed, with incomparable accuracy, Stephenson's claim that the agitation of mercury was largely due to vibrations conveyed by air. ${ }^{37}$ In April, Stephenson commissioned further experiments at Kensal Green to find the effects of vibrations from a train in a tunnel at different distances. He used a similar set-up as before, but without a second telescope to observe the image, previous trials having convinced him that "no material advantage would arise from the use of a telescope, since the sensibility of the eye, in detecting the vibration of the mercury, was far greater than [he] could have expected'. The engineer and the astronomer clearly had differing perceptions of the accuracy that these experiments required. These later trials suggested that 644 feet was the minimum distance between the observatory and a railway tunnel. The SER submitted these results on 2 May, but received a further

33 Correspondence, op. cit. (19), p. 24.

34 RGO/6/47, 'Airy to Sidney Herbert', 15 January 1845, p. 231.

$35 \mathrm{RGO} / 6 / 47$, 'Airy to Robert Stephenson', 17 January 1845, p. 235. These experiments can be seen in a broader context of debate over the role of experiment and small-scale modelling in engineering. On these questions and the science of shipbuilding at the British Association for the Advancement of Science see Ben Marsden, 'The administration of the "engineering science" of naval architecture at the British Association for the Advancement of Science, 1831-1872', Yearbook of European Administrative History (2008) 20, pp. 67-94.

36 Correspondence, op. cit. (19), pp. 27-29.

37 Correspondence, op. cit. (19), p. 29. 


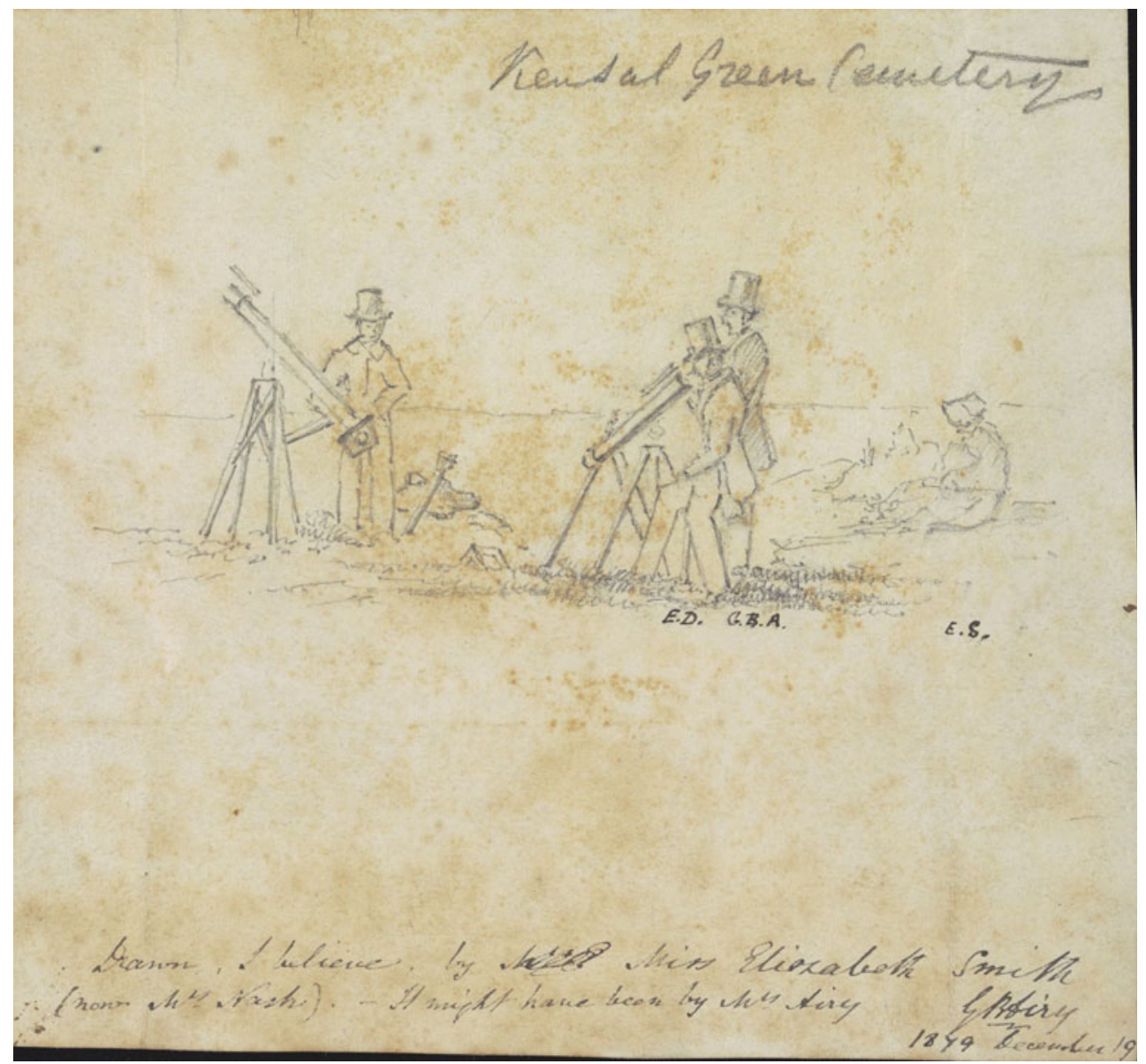

Figure 4. Drawing of collimator experiments in Kensal Green Cemetery, with Airy to the right of the observer employing the telescope. Airy noted on 19 December 1879 that this was drawn either by his wife Richarda Airy or by her sister Elizabeth Smith (later Elizabeth Nash). Loose drawing in RGO/6/47. Reproduced by kind permission of the Syndics of Cambridge University Library.

rejection from the Admiralty later that day. ${ }^{38}$ There had been much local hostility to the railway, with the churchwardens, overseers and governors of Greenwich parish voicing their opposition to the line to the Admiralty in February. Meanwhile, in March, the council of the British Archaeological Association warned that although the 'promotion of astronomical sciences' was not within its sphere of interest, it felt duty-bound to draw attention to the dangers the railway presented to the observatory. ${ }^{39}$

Despite this, Airy had resigned himself to the probability that a railway would be built and informed Edward Law (1790-1871), the newly appointed Conservative First Lord

38 Correspondence, op. cit. (19), pp. 33-34.

39 Correspondence, op. cit. (19), pp. 25, 30. 
of the Admiralty, that within ten years the park would surely have a line through it. He did not think that the observatory's interests would come before those of north Kent businesses and the SER. Indeed, the Morning Post had alleged that Airy had little objection to the railway, but 'did not like to express this opinion, from fear of offending the Admiralty'. ${ }^{40}$ Nevertheless, he wanted the observatory to have complete control over the weight and speed of passing trains and expected to be able to 'run experimental trains, of different weights, with different speeds, and different pressures of steam', to decide on permanent weights and speeds. ${ }^{41}$ Airy's resignation to the inevitability of a railway in the park, along with the sustained pressure of the SER, Stephenson and local social and business interests, convinced the Admiralty to seek a scientific consensus concerning the potential risk to the observatory. Royal Navy captain William Hamilton (18031881) wrote to several leading scientific authorities to find out broader opinions on the matter. He sent papers detailing the mercurial experiments, along with Airy's proposed restrictions, to Britain's leading mathematical and astronomical authorities, including John Herschel, Charles Babbage and James Challis. ${ }^{42}$

Herschel agreed with Airy's request for an Act of Parliament limiting the weight and speed of passing trains but warned that even a small tremor, if continued during the whole time of a star or planet passing through the most favourable part of the field of view of a telescope for its bisection under high magnifying powers, could not fail to be a source of annoyance or uncertainty'. Herschel felt that Airy's restrictions were insufficient and advocated a telegraphic communication from the observatory to the nearest station, which would allow the Astronomer Royal to prevent trains entering the park at moments of observation. ${ }^{43}$ Challis agreed, believing the mercurial experiments "very proper for determining the amount of disturbance to the ... Royal Observatory' and confirming that 'a degree of tremor so small as to be quite inappreciable by other means is sufficient to spoil an observation taken by reflection at the surface of mercury'. ${ }^{44}$ Challis, however, felt that Airy's trials underestimated the true damage to accurate observations. The use of mercury was vital because it provided a high degree of precision compared to the traditional use of a plumb line. He declared that 'the adoption of the reflection method is considered one of the greatest improvements in modern astronomy', and warned that should a train pass at an unpredicted time, or should the preparation of an observation overrun, the accuracy of reflection observations would be compromised. Furthermore, as the observatory relied on several fixed stars, to miss a transit would undermine its ability to produce accurate time readings. The railway threatened to cripple the observatory and damage the 'progress of astronomical science'. ${ }^{45}$

Thomas Robinson, director of Armagh Observatory, worried that Airy's experiments had not employed a sufficiently powerful telescope, offering only sixty-times magnification.

40 Anon., 'Railway committees', Morning Post, 1 May 1846, p. 3.

41 Correspondence, op. cit. (19), pp. 36-37.

42 Correspondence, op. cit. (19), p. 42.

43 Correspondence, op. cit. (19), pp. 42-43.

44 Correspondence, op. cit. (19), p. 44.

45 Correspondence, op. cit. (19), p. 45. 
The experiments did not, therefore, realistically model a transit observation. ${ }^{46}$ On the other hand, Charles Babbage thought Airy's experiments very credible. He suggested that iron trains might damage the magnetic work of the observatory, while steam could jeopardize accurate observations. Crucially, however, Babbage feared that the railway threatened future observation techniques not yet developed. As he put it, the 'progress of science has a continual tendency to demand an increase in the accuracy of astronomical observations; tremors that are now innocuous, may, in a few years, seriously interfere with improved means of observing'. ${ }^{47}$ Babbage saw this conflict between the observatory and the SER as a challenge between commerce and science, and feared that science might well lose out. He explained how the

advance of commerce and of mechanical arts, is urged on by far more powerful influences than those which, in this country at least, are applied to science. This advance can hardly fail, within a few years, to produce heavier engines and larger trains as well as their more frequent recurrence. ${ }^{48}$

Babbage believed that Airy's restrictions were insufficient and warned that the observatory's future would be risked by a railway's construction. Before long, he continued, it would have to be removed to a less exposed place. When the Board of Visitors of the Royal Observatory, the body charged with overseeing the operation of the institution, subsequently met to discuss the proposed railway on 6 June, Herschel proposed that with the 'advance of science so rapid, and the attention of astronomers so constantly directed to more and more minute corrections', there must be an 'entire absence of prospective danger' to the observatory. Four days later the Admiralty rejected Airy's compromises and reasserted its opposition to the railway. ${ }^{49}$

What really confirmed the failure of the SER's 1846 scheme was a series of reports which cast considerable doubt over the delicacy of Airy's vibration experiments. On 13 June 1846, Robinson sent a report of his own investigations on the effect of railway trains from Dublin. The results, he was convinced, were alarming, and persuaded him that no railway should be built within half a mile of any observatory. At a ruined distillery on the east bank of the river Dodder, Robinson had measured the vibrations of the Dublin and Kingstown Railway. Using two telescopes, 1,055 feet from the railway, he observed the reflection of a ridge tile on a roof onto a mercurial trough. This observation of reflected light through a telescope, Robinson believed, provided a more accurate investigation of terrestrial vibrations. On 5 June, while observing the light of Polaris reflected from a ridge tile, he observed that this method produced a 'blotty and elongated' image of the star, which remained distorted for seventy seconds. ${ }^{50}$

46 Correspondence, op. cit. (19), p. 49.

47 Correspondence, op. cit. (19), p. 46, original emphasis.

48 Correspondence, op. cit. (19), p. 46; on Babbage and state funding see Simon Schaffer, 'Babbage's intelligence: calculating engines and the factory system', Critical Inquiry (Autumn 1994) 21, pp. 203-227, 216; for Babbage's political economy see Charles Babbage, On the Economy of Machinery and Manufactures, London: Charles Knight, 1832.

49 Correspondence, op. cit. (19), p. 50.

50 Supplemental Report from Rev. Doctor Robinson on Probable Effects of Railway Passing Royal Observatory of Greenwich, PP 1846: 436 (in continuance of PP 375), p. 2. 
Robinson speculated that the ground conveyed sound vibrations faster than the air and submitted tables to substantiate these claims. Robinson trialled differently shaped troughs for the mercury and found that those that were circular revealed vibrations with greater accuracy than those that were rectangular (such as Airy had used); he thought a soup plate best for illustrating tremor. Robinson's claim that a circular trough was more sensitive was integral to his rejection of Airy's experiments; different results from trains of the same weight and speed could be obtained from differently shaped troughs. ${ }^{51}$

A second report came only a few days later, this time from the astronomer James South (1785-1867), who had been disturbed by the pressure that the SER was applying to the government to permit the scheme. South included details of a series of recently made experiments which he believed ruled out the possibility of a railway near the observatory, as well as raising questions over what constituted an adequate experiment to model railway vibrations. ${ }^{52} \mathrm{He}$ employed a telescope with a magnifying power of 250 , detecting tremors from passing omnibuses at 1,254 feet. At his observatory in Kensington, South performed vibration experiments on actual stellar observations. He argued that Airy's experiments were inaccurate because mercury for observations was usually positioned on a shelf, attached to a pier-carrying instrument. Modelling observations with the mercury trough on the ground did not reveal the full impact of vibrations, so he instead observed mercury positioned on steps; if he tapped his finger on the top step, the mercury was agitated, even at a gentle impulse. When Robinson visited and saw these effects, he too was worried, so the two of them invited the radical MP Joseph Hume (1777-1855) and any other interested parliamentarians to visit and see the experiment (Figure 5). On 25 May 1846, Hume attended, along with Conservative MP Robert Inglis (1786-1855). ${ }^{53}$ The work of the observatory was a concern that united MPs of varying ideological persuasions.

South's demonstration had political ramifications. On 5 June, Inglis raised a question in Parliament, asking Prime Minister Robert Peel whether he had any information on how the proposed railway would damage the Royal Observatory. Peel was known to be an enthusiastic patron of the natural sciences. In 1825, as Home Secretary, he had proposed to George IV the creation of two gold medals which the Royal Society would award for original scientific contributions. These were inaugurated in 1826, very much thanks to Peel's initiative. In 1835 he reformed the Civil List to allocate money through pensions to men of science and their families. ${ }^{54}$ The prime minister could therefore be relied upon to understand the gravity of the threat a railway presented to the observatory. Peel confirmed that the Admiralty had received two reports of mercurial experiments and promised to postpone the second reading of the Railway Bill for the line until the reports had been presented to MPs. ${ }^{55}$ In the newspapers, the SER

51 Supplemental Report, op. cit. (50), pp. 3 and 7.

52 Report of Sir J. South to Admiralty on Probable Danger of Railway Passing Royal Observatory, Greenwich, PP 1846: 470, p. 1.

53 Report of Sir J. South, op. cit. (52), pp. 3-4.

54 Roy MacLeod, 'Of medals and men: a reward system in Victorian science, 1826-1914', Notes and Records of the Royal Society of London (1971) 26(1), pp. 81-105, 82-83.

55 Commons Sitting of 5 June 1846, Hansard, third series, 87, col. 102. 


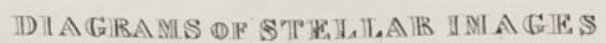

as seen by reflection firm the surface of Hercury and

alluded to in the preceding pages.
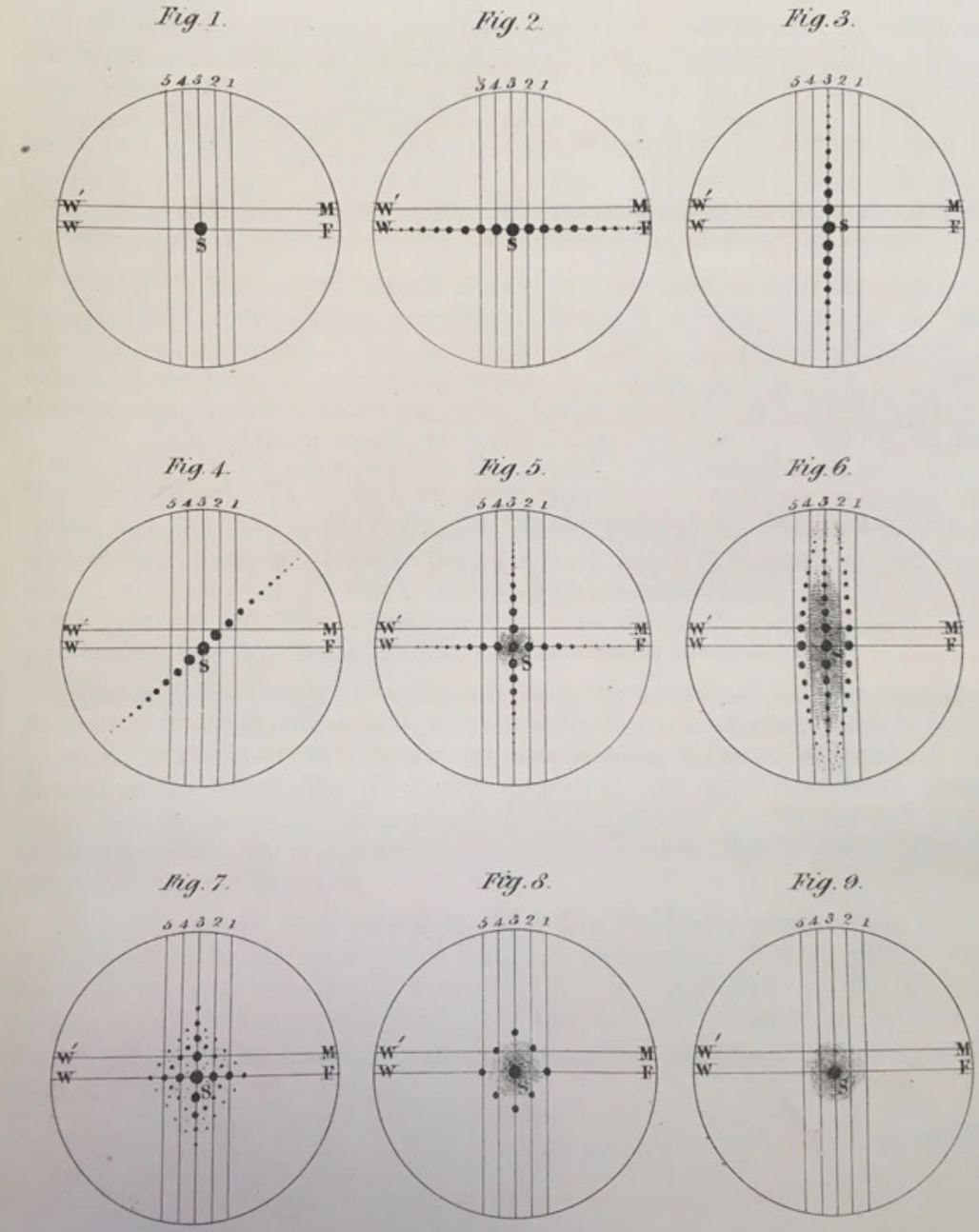

Figure 5. James South's diagrams to show the blurring of transit observations made on the reflected surface of mercury to illustrate the impact of railway vibrations. RGO/6/47, within document beginning p. 346. Reproduced by kind permission of the Syndics of Cambridge University Library. 
renewed efforts to build support for the railway. An article published on 8 June in The Times was highly critical of the government's lack of support for the project. While the 'progress of the railway system' was construed as evidence of 'the genius of the people' and their commerce, 'the Government had taken a passive, and, if anything, rather an antagonist course', failing to provide any guide or assistance. In the case of the Greenwich Park tunnel, Peel's administration had offered only 'tardy assent', ignoring the best interests of millions of potential passengers. At stake here was a much bigger question of the government's role in railway construction; this communication network had now to 'be considered as among the sinews of the State' and required government support. ${ }^{56}$ Furthermore, claims appeared in the newspapers that South held a financial interest in rejecting the scheme, thus undermining the integrity of his experiments. ${ }^{57}$

Ten days after his initial question in the Commons, Inglis again pressed Peel for dissemination of the experimental reports; the prime minister blamed the delay on 'some excited feeling ... mutually manifested between the scientific men engaged in this inquiry' and refused to publish what he considered to be 'mere matters of wrangling'. Nevertheless, he assured the Commons that everything 'of a scientific character - everything that was calculated to throw light on the merits of the question at issue, he would have much pleasure in laying before the House'. ${ }^{58}$ Amid increasing tensions over the proposed railway, Peel was careful about what experimental evidence was released, while Hamilton wrote in the Morning Post that another session of Parliament would have to pass before 'experiments may induce a more concurring opinion as to the real effects such a measure will have on an Observatory'. ${ }^{59}$ Despite this political confusion, the reports of South and Robinson, along with the consensus among astronomical authorities that the line threatened the observatory's accuracy, was enough to persuade the SER to abandon its planned connection.

\section{Relocating the observatory, 1862-1865}

Following the SER's failure in 1846, discussions over a railway near the observatory quietened down. Although the question of a Greenwich Park line was briefly raised in the early 1850 s, it was not until 1862 that plans for such a serious scheme resurfaced. ${ }^{60}$ This time, however, unlike in 1836 and 1846, it seemed very likely that the observatory would have to be relocated away from Greenwich. Airy first heard of the new Greenwich and Woolwich Railway project when its directors sounded him out regarding a proposed line from Deptford station into the park. ${ }^{61}$ Airy had no personal objection to a railway,

56 Anon., 'Extension of the Greenwich Railway', The Times, 8 June 1846, p. 5.

57 Report of Sir J. South, op. cit. (52), p. 5.

58 Commons Sitting of 15 June 1846, Hansard, third series, 87, col. 480.

59 W.A.B. Hamilton, 'The Greenwich Park tunnel and observatory', Morning Post, 15 June 1846, p. 2.

60 Correspondence with Admiralty Relative to Effect on Greenwich Observatory of Proposed Railway through Greenwich Park, PP 1865: 259, pp. 3, 4.

61 RGO/6/50, Buildings and Grounds, 1862 to 1867, September, 'Airy to Dunkin', 1 December 1862, p. 222. 
he claimed, but said that the general view of the government - and his own official stance - was that the park had to be protected from any risk to the observatory. However, giving 'an unauthorized expression of opinion', he maintained that

though a railway within the Park would shake us a little ... I believe that 800 feet distance from the observing rooms in a tunnel, or 1100 feet in open air, would ... reduce the tremor that it would not be inconvenient. Much might be done by agreement as to the speed of trains, with summary process for fining the station master in case of contravention. ${ }^{62}$

Subsequently, Airy received three proposed routes for the new Greenwich Railway, two of which included tunnels and a third passing by the bottom of the park, along the wall of the Royal Naval Asylum. In the face of a line of 'public convenience', Airy had 'very little objection to make to any of these' regarding the 'scientific interests of the Royal Observatory', but suspected that the government would object to protect the asylum. ${ }^{63}$

By early 1863, the London, Chatham and Dover Railway Company had a bill in Parliament for a route through Greenwich Park, which would connect the line to the SER's Greenwich branch; the two companies united to promote this plan, which would be of great value as it would link up with the newly built Metropolitan Railway (Figure 6). In February, Admiral Clarence Paget requested a report from Airy on the effects of the proposed lines, to which the Astronomer Royal asserted that vibrations from railways only affected observations at a thousand feet (a hundred feet under his 1836 experimental observations), and that if in a tunnel, a railway could be built around eight hundred feet from the observatory. ${ }^{64} \mathrm{~A}$ month later, the Duke of Somerset (1804-1885), the Whig First Lord of the Admiralty, informed Airy that while he did not want to threaten the Royal Observatory's ability to take accurate observations, he could not oppose the bill for the railway's construction when it would be of such immense 'convenience to a large population'. He requested new experiments on existing lines before Parliament reassembled, in order to inform a select committee to review the application. Somerset hoped that a circular tunnel, rather than a more customary semicircular tunnel, would reduce the vibrations of passing trains, while longitudinal sleepers might better absorb tremors. ${ }^{65}$

After a discussion with his son, Wilfrid Airy (1836-1925), over where the best location to replicate his mercurial trials on a railway in a circular tunnel would be, Airy selected a Metropolitan Railway station on the southern edge of Regent's Park, at Portland Place, to conduct fresh experiments. ${ }^{66}$ On 2 April 1863 he observed trains with the collimator, telescope and mercury trough on the North Kent Railway, at the entrance of a tunnel near Blackheath, and then repeated these investigations two days later at Regent's Park. At Blackheath, with trains passing at about twenty miles an hour, Airy found the wire image became unobservable at nine hundred feet or less

62 RGO/6/50, 'Airy to Thomas Adams', 2 December 1862, pp. 224-225, original emphasis.

63 RGO/6/50, 'Airy to John Lubbeck', 18 December 1862, pp. 232-233.

64 RGO/6/50, 'Airy to Clarence Paget', 24 February 1863, pp. 243-234.

65 RGO/6/50, 'Letter to Airy', 24 March 1863, pp. 262-263.

66 RGO/6/50, 'Wilfrid Airy to Airy', 28 March 1863, pp. 276-278; RGO/6/50, 'Airy to Alfred Austin', 28 March 1863, pp. 273-274. 


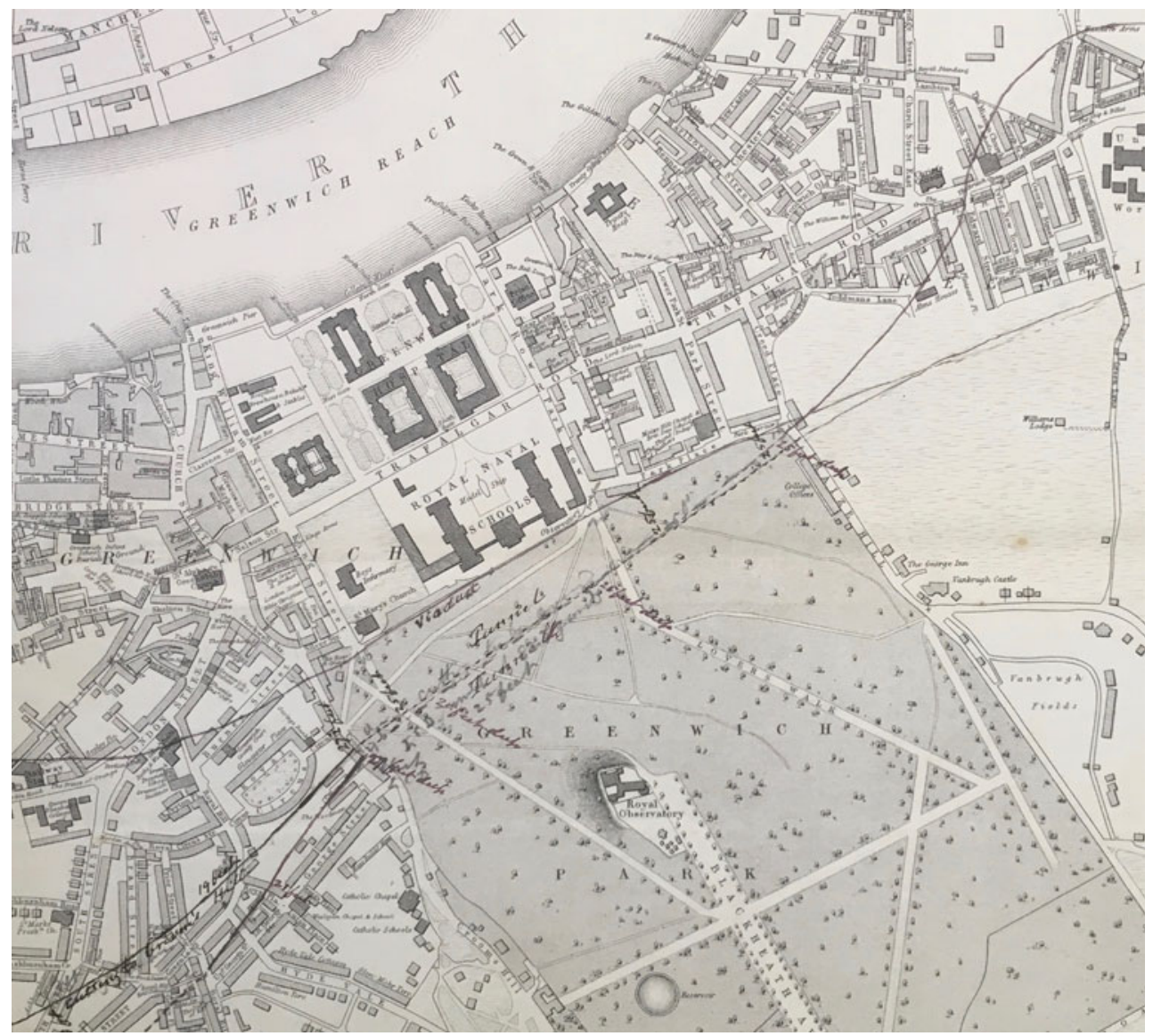

Figure 6. Various proposed routes for the London, Chatham and Dover Railway Company, with lines considered at the northernmost part of the park and further south to the observatory. RGO/6/ 50, p. 248. Reproduced by kind permission of the Syndics of Cambridge University Library.

from the railway, while at 1,560 feet the disturbance was minimal. In Regent's Park, cutting out a section of turf 864 feet from the passing Metropolitan Railway for the trough, Airy observed similar interference on astronomical observations, with the image of the wire disappearing under 970 feet, and good observations possible at 1,700 feet. These new experiments convinced Airy that the Astronomer Royal needed the legal power to limit trains passing in Greenwich Park to twelve miles per hour. $\mathrm{He}$ wanted the speed limit to be secured by an Act of Parliament specifying 'that the power of taking steps to enforce it be limited to the Astronomer Royal', with the authority 'to summon the Secretary, or some Officer of the Company', before Greenwich Police Court in the event of the speed limit being exceeded. ${ }^{67}$ 
Confident that the evidence produced provided a good account of how vibrations travelled from a tunnel, Airy submitted a report to the Admiralty, along with an assurance from the engineer of the London, Chatham and Dover Railway that no line would pass within 1,060 feet of the observatory's transit circle, and these were printed for Parliament later in April. The Board of Visitors, including John Couch Adams, Challis, Robinson, James South, George Stokes and William Whewell (with Airy also present), met on 24 April, and agreed that anything that might force the observatory to move to a new location would ruin its continuity and, with it, any claims to lead international astronomy. A relocation would 'deprive it of its acknowledged pre-eminence over all other astronomical observatories'. It was the observatory's long history which gave it authority beyond other observatories abroad. The visitors categorically rejected any proposed railway, confident that they would be 'supported by the approval of the whole scientific world'. ${ }^{68}$

Despite the failure of earlier proposals, and the continued opposition of the visitors and the Admiralty, the select committee considering the London, Chatham and Dover Railway's bid to build in Greenwich Park struggled to reject the scheme outright. In March 1863 a large public meeting gathered in the Lecture Hall at Royal Hill, producing an 'enthusiastic audience in favour' of the connection. The meeting's chairman, Mr Corkallis, a friend of several MPs, 'stated with some apparent authority' that vibrations would not be noticed at the observatory. This reportedly convinced those gathered. ${ }^{69}$ In Parliament, lobbyists continued canvassing support, citing census reports of 1841, 1851 and 1861 as evidence of the recent population expansion, as well as detailing the manufacturing and engineering works which would benefit from the connection. ${ }^{70}$ In the newspapers, the SER asserted it would contest the scheme's rejection with 'the most conclusive evidence, deduced from experiments' that the Royal Observatory's instruments would not be affected by passing trains, and criticized the government for undermining its own commitments to liberal free trade. As one journal put it,

Parliament ought to bear in mind the fact that the Government, by monopolizing all the land between Greenwich and Woolwich at this particular spot, virtually exercises a despotic sway over a large tract of country, and has it in its power ... to shut off the natural communication between two of the most important districts in the kingdom. ${ }^{71}$

Another local publication thought it odd that the Board of Visitors should refuse permission when Airy had initially consented, and claimed that there could

be no sound reason for disclaiming a fact which Professor Airy had established by a carefully made series of experiments that trains passing within a tunnel at a distance of 1,000 feet, and at a rate of speed not exceeding twelve miles an hour, could not produce by vibration any effect on the observatory instruments.

68 Minutes of Proceedings of Board of Visitors of Royal Observatory, April 1865, and Resolution Concerning Proposed S.E. and London, Chatham and Dover Railway Passing through Greenwich Park, PP 1865: 248, pp. 1-2.

69 RGO/6/50, 'Letter to Airy', 26 March 1863, pp. 266-267.

70 Correspondence, op. cit. (60), pp. 26-27.

71 RGO/6/50, 'Newspaper cutting' (1865), p. 405. 
In conclusion, the newspaper felt that a 'great deal too much stress ... has been laid upon the effect of vibration of the air, in astronomical observations'. ${ }^{72}$ This was a very public questioning of what constituted an appropriate engineering experiment and of who was competent to perform it.

In the face of this clamour, the Admiralty certainly thought the line a realistic prospect, warning that, if allowed in the park, the company would have to be forced by Act of Parliament to pay for the building of a new Royal Observatory, away from Greenwich. ${ }^{73}$ Somewhat spooked at the resilience of the new railway scheme, the Admiralty requested Edward Sabine (1788-1883) to call an emergency meeting of the Board of Visitors. As president of the Royal Society, Sabine was automatically chairman of the Royal Observatory's Board of Visitors. ${ }^{74}$ In the Royal Society's headquarters at Burlington House, the visitors again demanded that the line be rejected, maintaining that the precision of astronomical methods is continually and rapidly progressive, so that tremors which now might be considered not intolerable would, in all probability, in the progress of time, become deservedly so considered' ${ }^{75}$

The SER changed tack in 1864; instead of contending experimental evidence as to the effect of vibrations, the company proposed to remove the Royal Observatory altogether. In August, astronomer Warren De la Rue (1815-1889), on behalf of the Board of Visitors, asked Airy if there would be 'any insurmountable objection to the removal of the Greenwich Observatory to another site' if 'a most liberal sum were paid to reerection of a scale of great efficiency and magnificence' ${ }^{76}$ This request clearly shocked Airy, who angrily responded that this was impossible. ${ }^{77}$ By this stage Airy was growing increasingly hostile to railway schemes, and the suggestion that the SER would seriously campaign to have the observatory removed from the park was a turning point. While at first he had attempted to cooperate with various rail promoters, providing there were legal restrictions in place and the Astronomer Royal maintained authority over the movement of locomotives, from 1863 trust between Airy and the SER collapsed rapidly. This had been a company with which Airy had had close connections, and with which he had enjoyed great success in collaborating to disseminate telegraphic time signals. Now, however, the company's aggressive pursuit of profits and lack of transparency agitated the astronomer.

Regardless of the Astronomer Royal's objections, the SER was keen to force legislation through Parliament for the new line, with the removal of the observatory a serious proposal. ${ }^{78}$ In response to the House of Commons bill in February 1865, Airy informed Paget that although the measure was an SER scheme, it also had the support of the London, Chatham and Dover Railway, and that these two 'powerful companies'

72 RGO/6/50, 'Local newspaper cutting' (1865), p. 406.

73 Correspondence, op. cit. (60), pp. 9-10.

74 P.S. Laurie, 'The Board of Visitors of the Royal Observatory - I: 1710-1830', Quarterly Journal of the Royal Astronomical Society (1967) 7, pp. 169-185, 184.

75 Correspondence, op. cit. (60), pp. 16, 18.

76 RGO/6/50, 'Warren De la Rue to Airy', 6 August 1864, p. 343, original emphasis.

77 RGO/6/50, 'Airy to Warren De la Rue', 6 August 1864, p. 344.

78 RGO/6/50, 'Warren De la Rue to Airy', 8 August 1864, p. 346. 
were capable of securing favourable legislation. ${ }^{79}$ Citing his mercurial experiments, Airy asserted that '[e]very train passing through the tunnel would be felt at the Observatory, and would to a certain degree interfere with the astronomical proceedings of the Observatory'. Although Airy was confident he could resolve any difficulties with mechanical contrivances, 'these remarks apply only to the instruments on the ground floor'. There was one crucial 'instrument, the Large Equatoreal, which from necessity is in a lofty building, and which ... would probably feel the tremor much more than the lower instruments' ${ }^{80}$ For this there appeared to be no solution. Combined with Airy's growing exasperation at the aggressive line that promoters of a park railway had taken, the recent installation of the large equatorial seems to have changed the Astronomer Royal's earlier position. While in the 1830 s he was not inherently opposed to such a route, by the mid-1860s he was determined to reject any scheme that might disrupt the observatory's work.

As for suggestions that the observatory should be removed altogether, he warned that 'no compensation could be made, in money, for permanent injury to the Greenwich Observatory, as the leader in some parts of its science, and as the sole promoter of one of the most important branches, is notorious to the scientific world'. Appealing to notions of national prestige, he pointed out that the

name of Greenwich, as the origin of terrestrial measure of position, is known all over the world: and, whatever may happen, the National Observatory must be on the meridian of Greenwich. And in vain will another site be sought, possessing the advantages of enclosure in a Royal Park, of proximity to London, and of proximity to the Thames. ${ }^{81}$

Airy hereby reiterated that Greenwich was the only place the observatory could be located as it had to be on the Thames to provide chronometric communications for the Royal Navy and merchant vessels, and on the meridian for astronomical work. By changing location, Airy implied that the authority of the observatory and of the Greenwich meridian would be endangered. For example, he recalled how, when Pulkova Observatory, near St Petersburg, was established, its director immediately took measures for finding the longitude for Greenwich, 'in order that the Russian longitude might be referred to the meridian of Greenwich'. The name of Greenwich was of such global eminence that Airy implored the government to protect it from 'the traffic of the powerful railways'. ${ }^{82}$

The seriousness of the SER's proposals to remove the observatory convinced Airy that the company had little interest in safeguarding British astronomical science and was only concerned with maximizing its profits. In May 1865 he wrote that

the conduct of the Promoters - in maintaining perfect secrecy both on their design and on its details, and presenting it only when no change could be made - seems to render it necessary

79 RGO/6/50, 'Airy to Clarence Paget', 24 February 1865, pp. 372-373.

80 RGO/6/50, 'Airy to Clarence Paget, memorandum', 24 February 1865, p. 381.

$81 \mathrm{RGO} / 6 / 50$, op. cit. (80), p. 382; on Airy's views of Britain's religious destiny in relation to his government work see Courtney, op. cit. (2), pp. 136, 144.

$82 \mathrm{RGO} / 6 / 50$, 'Notes by George Biddell Airy, Astronomer Royal, for the committee on the extension of the South Eastern Railway', May 1865, p. 441. 
for the protectors of the Observatory and the Park to examine the plan with greater severity than would otherwise have been required.

Airy concluded that the SER could have built the proposed route in front of the hospital, along the public road, but that the company's motive for sticking to the park was clearly 'cheapness'; going through the park would save the expense of removing houses. ${ }^{83}$ These allegations of cost-cutting brought the SER's aspirations to a swift termination. The company did try again in 1870 with yet another bill in Parliament, essentially the same as that of 1865 . Airy maintained his opposition, claiming that the observatory's utility was 'not simply national: it is universal'. ${ }^{84}$ Towards the end of his tenure as Astronomer Royal, Airy lamented that the subject of proposed railway schemes had occupied such a substantial proportion of his time and energy for the previous thirty years. $^{85}$

\section{Conclusion}

When Greenwich was fixed as the international prime meridian in 1884, part of its claim to authority was the continuity and permanence of the Royal Observatory, yet less than twenty years earlier, its location had been in serious doubt. The construction of a railway through Greenwich Park, at the expense of the observatory's ability to produce accurate astronomical observations, was a realistic prospect for over thirty years, and the motive for this was profit. Railway companies preferred a park route simply because it was cheap, and while undoubtedly helping to disseminate standard time, they showed little concern for the welfare of the scientific institution that produced it. After 1865, there were further efforts to build a park connection, including in 1868 and 1870, but these were tentative and lacked any conviction that either Airy or the government would drop their opposition. ${ }^{86}$ In 1873, the SER opened a new station just north of the observatory, at Maze Hill, which acted as a terminus for the company's north Kent services. Five years later, a cut-and-cover tunnel was constructed connecting Maze Hill with Greenwich town, but this was built through the grounds of the Royal Naval Asylum, far from the observatory. Eventually the Royal Observatory was relocated, but this did not occur until well into the twentieth century. The electrification of nearby railway lines in the 1890s, extended in the 1920s, made magnetic observations difficult, and so a new site for this work was selected near Abinger in Surrey in 1924. Following this, the decision was taken in 1947 to relocate the rest of the observatory to

83 RGO/6/50, 'Airy to the Duke of Somerset', 22 May 1865, pp. 414-415.

84 RGO/6/51, 'Memorandum to Airy', 24 February 1870, p. 355; on Airy and utility see Allan Chapman, 'Private research and public duty: George Biddell Airy and the search for Neptune', Journal for the History of Astronomy (1988) 19, pp. 121-139.

85 RGO/6/51, 'Airy to Eborall', 19 November 1868, p. 311; RGO/6/51, 'Airy to De la Rue', 21 November 1868, p. 313.

86 RGO/6/51, 'Thomas Cabban and W. Gurley Smith to Airy', 4 April 1868, p. 296; RGO/6/51, 'Fuller V. Marr to William Augerstein', 3 June 1868, p. 299; RGO/6/51, 'Airy to Baillie Hamilton', 8 June 1868 , p. 300 . 
Herstmonceux Castle, Sussex, in response to London's worsening smog and light pollution. ${ }^{87}$

The continuing tendency of railway companies to favour the park over more northerly routes was very much financially motivated. Babbage's claim in the 1840s that railway schemes for Greenwich Park represented a conflict between unfettered capitalism and astronomical science appeared vindicated by 1865 . In the early years of railway construction, private companies could not be trusted to safeguard the observatory and it required government intervention to maintain the institution's scientific integrity in the face of commercial expansion. The threat of increasing traffic was not unique to the Royal Observatory. At the University of Cambridge's observatory, John Couch Adams faced a similar challenge during the late 1870s. Here, passing road carts and wagons caused similar vibrations; in 1882 Thomas Berney wrote to Adams recalling how, on visiting the observatory several years earlier as an undergraduate, he observed vibrations disturbing a transit instrument. ${ }^{88}$ Similarly, Robinson felt the construction of a railway near Armagh Observatory permanently undermined the accuracy of his astronomical readings; the tremors were so disruptive that observations by reflection were 'uncertain for an average of four and a half minutes after a train leaves a station'. ${ }^{89}$ Across Britain and Ireland, the relationship between astronomical and commercial interests was, if not in outright opposition, extremely complicated and strained. While at Greenwich the observatory found support from the Admiralty and Parliament, where state intervention was absent Babbage's prophecy that capital would succeed at the expense of science was realized.

87 Meadows, Greenwich Observatory, op. cit. (2), pp. 18-20; W.H. McCrea, The Royal Greenwich Observatory, London: Her Majesty's Stationery Office, 1975, pp. 45-50.

88 St John's College Library, Cambridge (SJC), Adams/12/12/3, 'F.C. Penrose to John Couch Adams', Easter Monday 1877; SJC, Adams/5/23, 'Thomas Berney to John Couch Adams', 9 March 1882.

89 Minutes, op. cit. (68), p. 2. 